University for Business and Technology in Kosovo

UBT Knowledge Center

UBT International Conference

2018 UBT International Conference

Oct 27th, 9:00 AM - 10:30 AM

\title{
Capital structure in construction sector: what does it depend on?
}

Liudmila Guzikova

Peter the Great Saint-Petersburg Polytechnic University, guzikova@mail.ru

Follow this and additional works at: https://knowledgecenter.ubt-uni.net/conference

Part of the Business Commons

\section{Recommended Citation}

Guzikova, Liudmila, "Capital structure in construction sector: what does it depend on?" (2018). UBT International Conference. 282.

https://knowledgecenter.ubt-uni.net/conference/2018/all-events/282

This Event is brought to you for free and open access by the Publication and Journals at UBT Knowledge Center. It has been accepted for inclusion in UBT International Conference by an authorized administrator of UBT Knowledge Center. For more information, please contact knowledge.center@ubt-uni.net. 


\title{
Capital structure in construction sector: what does it depend on?
}

\author{
Liudmila Guzikova \\ Peter the Great Saint-Petersburg Polytechnic University, Polytekhnicheskaya 29, \\ 195251, Saint-Petersburg, Russia \\ guzikova@mail.ru
}

\begin{abstract}
Construction is one of the basic branches of national economy creating the material basis for the most of economic and social activities, as well as of the personal welfare and being of the people. Construction sector consists of enterprises including large, medium and small businesses. The interaction of different types of construction business allows ensuring the proper volume of construction and providing flexible and quick response to demand changes, trends, and challenges. Construction companies need capital to support their performance and they create capital structure combining the available sources of equity and debt. There are two well-known theoretical provisions used in analysis of the capital structure of the companies: a) demand for capital significantly changes within the life cycle of the company; b) opportunities to use different capital sources vary in accordance with the life cycle and the size of the company. The objective of the current research is to identify the difference in the capital structure of construction companies of different age and size. The object under consideration is the capital structure of Russian construction companies. The methods of financial and economic analysis and statistical methods are used for investigation. The results and conclusions of the research can be useful to the heads and financial managers of construction companies and to the governing bodies of the construction sector.
\end{abstract}

Keywords: construction companies, capital structure, sources of financing, equity, debt, age of the company, size of the company 


\section{Introduction}

Theoretical studies of capital structure, which implies the ratio of equity and debt capital, began in the 30 s of the 20 century and experienced a surge of interest in the late 50's - early 60's. It is generally recognized that the main contribution to the development of this theory was made by Modigliani and Miller [10]. In the following period, much of the capital structure research was of an empirical nature.

Most researchers consider the capital structure as an object of purpose-directed management for financial managers of companies. Efforts are applied mainly to the formation of the optimal structure. Financial managers of companies constantly face the problems of finding sources for financing and forming in some sense the best combination of these sources. As a criterion of optimization, the price of capital and the return on equity are most often used. The issue of the capital structure determinants is widely discussed both from the point of view of the availability of sources and from the point of view of optimizing their combination.

In a number of works, for example, $[3 ; 5 ; 8 ; 13]$, the capital structure is viewed dynamically from the standpoint of the company's development and the stages of its life cycle.

The sectoral aspect is also reflected in studies of the capital structure. The importance of construction as a sphere that creates long-term capital goods allows us to assert that financial decisions made and implemented by construction companies' managers are important not only for these companies and their economic environment, but also for the economies of territories and countries. There are a number of works devoted to studying the capital structure of construction companies in different countries, for example, Malaysia [1; 9], Saudi Arabia [7], South Korea [4].

The structure of the capital of Russian construction companies has not so far attracted the attention of researchers. However, there are works devoted to revealing the features of capital structure formed by Russian companies of other industries, for example, $[6 ; 11 ; 12]$. Among the factors that allow purpose-directed formation of a capital structure, ensuring the conditions for its most effective use in each company, Elmurzaeva [6] mentions industry-specific activities; the stage of the life cycle; commodity and financial markets' conjuncture; level of the return on assets; the attitude of the creditors; the level of profit taxation; financial mentality of owners and managers of the company.

The purpose of this paper is to analyze the capital structure of Russian construction companies, taking into account the characteristics of size and age. The result of the research should allow forming a basis for forecasting the state of the industry and making managerial decisions in individual companies and at the branch and regional levels.

\section{Data and Methods}

The data for the study are the accounting data for 2016 of the construction industry companies, sub-sector "construction of residential and non-residential buildings", 
operating in the Leningrad region of the Russian Federation, contained in the database SPARK (Interfax). The initial sample, containing information on 805 companies, was reduced through the successive implementation of the following steps:

1) Elimination of companies in the liquidation and reorganization phase, after which the sample was reduced to 757 companies marked as active;

2) Elimination of companies with zero or negative equity, after which there were 584 companies left in the sample:

3) Elimination of companies with a negative value of at least one of the indicators "net profit", "profit before tax", "gross profit", after which 210 companies that can be considered as successfully survived in 2016 and continuing their activity, left in the sample/

Thus, relatively successful companies of different sizes are the object of comparison. Among the remaining companies in the sample are 8 large enterprises, 10 medium-sized enterprises, 33 small enterprises and 159 microenterprises. It should be noted that in accordance with Russian legislation, the criteria "number of employees" and "amount of revenue") are used to determine the size of the enterprise. The assets, that is total capital, is not a criterion indicator

The analysis used data on the age of companies, the total amount of capital, the amount of equity, long-term and short-term borrowed capital, long-term and shortterm bank loans.

The research methodology consists in distinguishing groups of companies based on their type and calculation indicators that characterize the capital structure [2]:

1) financial leverage = debt capital / equity;

2) proportion of long-term debt = long-term debt/ total capital;

3) proportion of short-term and long-term loans = (short-term loans + long-term loans) / total capital.

For the indicator "age of the company" and indicators characterizing the capital structure, descriptive statistics were calculated. Based on the analysis of descriptive statistics the internal structure of the groups was assessed, similarities and differences between groups of enterprises were revealed. Correlations were calculated to determine the relationship between the age of the company and the capital structure indicators.

\section{Results}

Descriptive statistics for the age of companies and the index of financial leverage are shown in Table. 1.The lower boarder of the age of active medium and large companies (9 and 5 years, respectively) is significantly higher than for small and microenterprises (1.5 years), but the upper limit can be considered approximately the same, which confirms the possibility of implementing a strategy of preserving the size in the construction market. The fact that longevity in all groups is a fairly rare phenomenon is confirmed by the positive values of the skewness indicators, which show that age less than the average prevails in the sub-samples. The conclusion is supported by the fact that in all groups the mode and the median are less than the mean value. 
The minimum values of financial leverage show that among the large companies there are none that can be called financial independent, as the amount of debt capital used exceeds equity. In the group of medium-sized companies, there are those with a financial leverage less than 1, which makes them relatively financially independent, and among small and micro enterprises there are those that do not use borrowed capital at all. Median values of financial leverage show that in all groups, more than half of the companies are significantly financially dependent, with microenterprises and large companies relatively less dependent.

Table 1. Descriptive statistics of the companies' age and financial leverage

\begin{tabular}{|l|r|r|r|r|r|r|r|r|}
\hline \multirow{2}{*}{ Statistic } & \multicolumn{3}{|c|}{ Age of the company } & \multicolumn{5}{c|}{ Financial leverage } \\
\cline { 2 - 9 } & Large & Medium & Small & Micro & \multicolumn{1}{c|}{ Large } & \multicolumn{1}{c|}{ Medium } & \multicolumn{1}{c|}{ Small } & \multicolumn{1}{c|}{ Micro } \\
\hline Mean & 16.50 & 15.40 & 11.42 & 9.28 & 8.14 & 15.21 & 176.23 & 194.67 \\
\hline $\begin{array}{l}\text { Standard } \\
\text { error }\end{array}$ & 1.87 & 2.14 & 1.31 & 0.51 & 2.20 & 8.30 & 152.92 & 100.06 \\
\hline Median & 15.75 & 15.50 & 10.00 & 8.00 & 6.29 & 7.99 & 7.14 & 5.95 \\
\hline Mode & 15.00 & 15.50 & 4.50 & 4.50 & - & - & - & - \\
\hline $\begin{array}{l}\text { Standard } \\
\text { deviation }\end{array}$ & 5.28 & 6.77 & 7.52 & 6.48 & 6.22 & 26.23 & 878.45 & 1261.74 \\
\hline $\begin{array}{l}\text { Sample } \\
\text { variance }\end{array}$ & 27.93 & 45.88 & 56.61 & 42.00 & 38.67 & 688.08 & 771672.74 & 1591980.26 \\
\hline Kurtosis & 1.14 & -0.36 & -0.50 & -0.08 & -1.40 & 8.84 & 32.88 & 128.92 \\
\hline Skewness & 0.68 & 0.26 & 0.65 & 0.92 & 0.56 & 2.91 & 5.73 & 11.00 \\
\hline Range & 17.50 & 21.00 & 25.50 & 24.50 & 15.62 & 87.66 & 5065.58 & 15191.85 \\
\hline Minimum & 9.00 & 5.00 & 1.50 & 1.50 & 1.34 & 0.59 & 0.00 & 0.00 \\
\hline Maximum & 26.50 & 26.00 & 27.00 & 26.00 & 16.96 & 88.25 & 5065.58 & 15191.85 \\
\hline
\end{tabular}

The minimum values of financial leverage show that among the large companies there are none that can be called financial independent, as the amount of debt capital used exceeds equity. In the group of medium-sized companies, there are those with a financial leverage less than 1, which makes them relatively financially independent, and among small and micro enterprises there are those that do not use borrowed capital at all. Median values of financial leverage show that in all groups, more than half of the companies are significantly financially dependent, with microenterprises and large companies relatively less dependent.

To study the relation between the age of companies and their financial leverage, point diagrams were constructed, where the value of the financial leverage is plotted along the horizontal axis, and the age is plotted along the vertical axis (Fig. 1). It should be noted that when drawing diagrams for small and medium-sized companies, the maximum values of the leverage which exceed the corresponding mean values more than 28 and 78 times (!), were discarded. Diagrams clearly show:

1) the average level of financial leverage in all groups reflects a high financial dependence, with the average level of financial leverage and the size of companies being inversely related;

2) in all groups, most companies have a level of financial leverage below the average;

3) Each group has a relatively small number of companies that have a financial leverage corresponding to an extremely high degree of financial dependence; 
4) In groups of larger companies, higher leverage ratios are characteristic for companies whose age is above the average, while in groups of smaller companies, extremely high values are characteristic for companies whose age is below average.

In the Russian accounting, the following forms of equity are distinguished: authorized capital, additional capital, reserve capital and retained earnings. Long-term debt capital includes long-term loans, deferred tax liabilities and other long-term debt. Short-term debt capital consists of short-term loans, accounts payable, deferred income and other current liabilities.

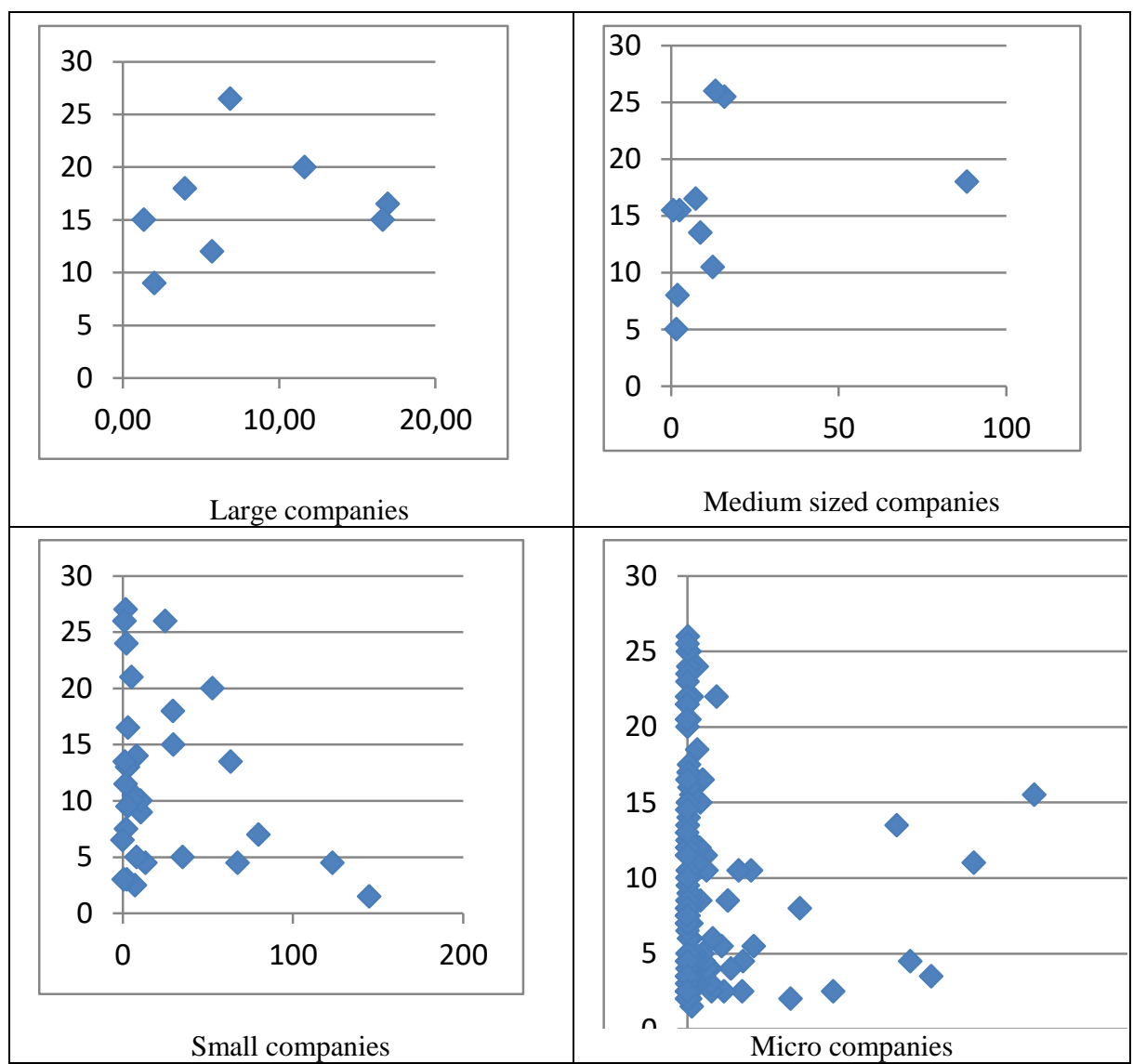

Fig. 1. Relation between the age of companies and their financial leverage

The nature of the construction companies' activities involves the implementation of long-term projects, which requires appropriate funding sources. It seems obvious that at some stages of the construction cycle, debt financing can be a much more profitable option than using a larger amount of equity that will be unused during other stages of the construction cycle. The use of bank loans to finance operations, on the one hand, reflects the compliance of companies with bankable solvency requirements, and, on the other hand, the aspiration of companies to use bank loans with the given level of interest rates, and the availability of alternative options for companies. Table 
2 shows descriptive statistics for indicators of the proportion of long-term borrowed funds and the proportion of bank loans.

A wide range of indicators should be noted, which is confirmed by relatively high values of the standard error. Microenterprises have the highest level of long-term financing, but at the same time the level of bank loans use is the least. For most companies in all groups, the level of long-term financing is insignificant, as does the level of use of bank loans.

Table 2. Descriptive statistics of the proportion of long-term debt capital and proportion of bank loans

\begin{tabular}{|c|c|c|c|c|c|c|c|c|}
\hline \multirow[t]{2}{*}{ Statistic } & \multicolumn{4}{|c|}{$\begin{array}{c}\begin{array}{c}\text { Proportion of long-term debt } \\
\text { capital }\end{array} \\
\end{array}$} & \multicolumn{4}{|c|}{ Proportion of bank loans } \\
\hline & Large & Medium & Small & Micro & Large & Medium & Small & Micro \\
\hline Mean & 0.08 & 0.09 & 0.06 & 0.18 & 0.14 & 0.08 & 0.11 & 0.08 \\
\hline Standard error & 0.04 & 0.03 & 0.02 & 0.09 & 0.04 & 0.02 & 0.02 & 0.03 \\
\hline Median & 0.05 & 0.00 & 0.00 & 0.01 & 0.15 & 0.00 & 0.00 & 0.06 \\
\hline Mode & - & 0.00 & 0.00 & 0.00 & - & 0.00 & 0.00 & 0.00 \\
\hline $\begin{array}{l}\text { Standard } \\
\text { deviation }\end{array}$ & 0.10 & 0.20 & 0.20 & 0.28 & 0.12 & 0.12 & 0.23 & 0.09 \\
\hline $\begin{array}{l}\text { Sample } \\
\text { variance }\end{array}$ & 0.01 & 0.04 & 0.04 & 0.08 & 0.01 & 0.01 & 0.05 & 0.01 \\
\hline Kurtosis & 1.35 & 5.54 & 11.60 & 0.81 & -1.68 & 0.73 & 5.17 & -0.99 \\
\hline Skewness & 1.44 & 2.49 & 3.54 & 1.51 & 0.06 & 1.43 & 2.45 & 0.69 \\
\hline Range & 0.28 & 0.73 & 0.98 & 0.73 & 0.30 & 0.38 & 1.02 & 0.24 \\
\hline Minimum & 0.00 & 0.00 & 0.00 & 0.00 & 0.00 & 0.00 & -0.04 & 0.00 \\
\hline Maximum & 0.28 & 0.73 & 0.98 & 0.73 & 0.30 & 0.38 & 0.97 & 0.24 \\
\hline
\end{tabular}

It is reasonable to assume that the longer the company successfully (which in our case is confirmed by the very fact of its presence in the sample) works in the market, the better is its reputation as a borrower, which should allow its using long-term debt capital and bank loans. The converse assumption that the possibility of using longterm debt and bank loans contributes to the company's longevity is also grounded. The analysis of correlation coefficients between the age of companies and proportions of long-term capital and of bank loans (Table 3) shows that this dependence is not negligible only in a small group of medium-sized companies. An indistinct relationship between age and the availability of bank lending can be traced in a small group of large companies. However, the links noted are not so close that access to borrowing could be unequivocally explained by the age of the company or vice versa.

Table 3. Correlation of the company's age with the capital structure indicator

\begin{tabular}{|l|r|r|r|r|}
\hline \multirow{2}{*}{\multicolumn{1}{|c|}{ Indicator }} & \multicolumn{4}{|c|}{ Group of companies } \\
\cline { 2 - 5 } & Large & Medium & \multicolumn{1}{c|}{ Small } & \multicolumn{1}{c|}{ Micro } \\
\hline Proportion of long-term debt & $-0,13$ & 0,544 & 0,099 & $-0,05$ \\
\hline Proportion of loans & 0,422 & 0,297 & $-0,012$ & $-0,004$ \\
\hline
\end{tabular}




\section{Conclusions}

Analysis of the capital structure of Russian construction companies allowed drawing a number of conclusions that determine the further directions of research and practical work of managers. Approximate equality of the maximum age of companies in all groups shows the possibility of maintaining the stable size of the company for a long time, which is possible for the smaller companies in cases of a) working in a limited niche; b) timely separation of new companies as business grows. Further research can be aimed at analyzing the strategies of construction companies, and from the standpoint of practice, the experience of successful "long-livers" deserves attention.

The extremely high financial leverage of most companies combined with a noticeable predominance of short-term borrowed funds is evidence of the unstable state of the industry as a whole. In the foreseeable future, this may lead to a massive loss and subsequent bankruptcies. A possible scenario for development is the massive acquisition of smaller, relatively stable companies by the larger companies or mergers of several small companies. The direction of research may be the study of the optimal ratio of the own and debt capital in dynamics depending on the stage of implementation of construction projects. The same question should be interesting for financial managers of construction companies.

The low level of bank loans using confirms the low assessment of construction companies as potential borrowers, by banks. In part, this may take place due to the inflexibility of the loan products offered and the lack of attention to the specific nature of the activities of construction companies. The research can be devoted to the development of special methods for comprehensively assessing construction companies' solvency. Stable relations of construction companies with banks are possible on the basis of more flexible financing options, the development of which should be carried out by banks.

\section{References}

1. Baharuddin, N.S., Khamis, Z., Mahmood, W.M.W., Dollah, H.: Determinants of Capital Structure for Listed Construction Companies in Malaysia. Journal of Applied Finance \& Banking 1(2), 115-132 (2011).

2. Brealey, R.A., Myers, S.C., Allen F.; Principles of Corporate Finance. 9th edn. New York: McGraw-Hill Education (2008).

3. Castro, P.C., Tascón, M.T., Amor-Tapia, B.: The Role of Life Cycle on Capital Structure. Pecvnia 19, 131-155 (2014).

4. Choi, J.-K., Yoo, S.-K., Kim, J.-H., Kim, J.-J.: Capital Structure Determinants among Construction Companies in South Korea: A Quantile Regression Approach. Journal of Asian Architecture and Building Engineering 13(1), 93-100 (2014).

5. DeHan, C.P.: Capital Structure over the Life Cycle. Advances In Business Research 5, 16-32 (2014).

6. Elmurzaeva, R.A.: Methodical approach to the analysis of capital structure financing. Russian Entrepreneurship 12 (4), 74-80 (2011). [In Russian]

7. Ibn-Homaid, N.T., Tijani, I.A.: Financial Analysis of a Construction Company in Saudi Arabia. International Journal of Construction Engineering and Management 4(3), 80-86 (2015). 
8. Tian, L., Han, L., Zhang, S.: Business Life Cycle and Capital Structure: Evidence from Chinese Manufacturing Firms. China \& World Economy 23 (2), 22-39 (2015).

9. Mahmood, W.M.W., Zakaria, R.: Profitability and Capital Structure of the Property and Construction Sectors in Malaysia. Pacific Rim Property Research Journal 13(1), 92-105 (2007). 10. Modigliani, F., Miller, M.H.: The Cost of Capital, Corporation Finance and the Theory of Investment. The American Economic Review 48(3), 261-297 (1958).

11. Nikitushkina, I.V., Makarova, S.G. eds,: Capital structure of the corporation: theory and practice: Monograph. Moscow: Economic Faculty of Moscow State University (2013). [In Russian]

12. Sharikova, O.V.: Dynamic modeling of capital structure factors of Russian organizations. Analysis and audit 3. 193-199 (2011). [In Russian]

13. Titov, V.A., Dolgopolov, A.A.: Interdependence of Capital Structure and Stage of Life Cycle of Production Company. Fundamental Research 6-5, 1018-1022 (2014). 